\title{
Assessing Carbon Stocks, Carbon Sequestration, and Greenhouse-Gas Fluxes in Ecosystems of the United States Under Present Conditions and Future Scenarios
}

The Energy Independence and Security Act of 2007 (EISA; U.S. Congress, 2007) requires the U.S. Department of the Interior (DOI) to develop a methodology and conduct an assessment of carbon storage, carbon sequestration, and greenhouse-gas (GHG) fluxes in the Nation's ecosystems. The U.S. Geological Survey (USGS) has developed and published the methodology (Zhu and others, 2010) and has assembled an interdisciplinary team of scientists to conduct the assessment over the next 3 to 4 years, commencing in October 2010. The assessment will fulfill specific requirements of the EISA by-

- Quantifying, measuring, and monitoring carbon sequestration and GHG fluxes using national datasets and science tools such as remote sensing and biogeochemical and hydrological models

- Evaluating a range of management activities for their effects on carbon-sequestration capacity and the reduction of GHG fluxes

- Assessing effects of climate change and other controlling processes (including wildland fires) on carbon uptake and GHG emissions from ecosystems

The geographic and temporal scope of the assessment is based on the requirements of the EISA. The assessment will cover major terrestrial and aquatic ecosystems in all 50 States, including forests, grasslands/shrublands, croplands, wetlands, rivers, lakes, impoundments, estuaries, and coastal waters (fig. 1). The primary terrestrial carbon pools to be assessed are biomass, dead organic matter, soils and sediments, soil organic matter, and harvested wood, which are consistent with those recognized by the Intergovernmental Panel on Climate Change (IPCC) and commonly used in other inventory programs. Aquatic pools will include dissolved organic carbon, dissolved inorganic carbon, and particulate organic carbon that are carried in surface and coastal waters. The assessment will provide estimates of production, consumption, and transition of carbon among pools. The flux (or flow) of carbon dioxide $\left(\mathrm{CO}_{2}\right)$, methane $\left(\mathrm{CH}_{4}\right)$ and nitrous oxide $\left(\mathrm{N}_{2} \mathrm{O}\right)$ from these pools into the atmosphere also will be estimated (fig. 2).

The assessment will be conducted at a regional scale, using modified Environmental Protection Agency level II ecoregions (based on Omernik, 1987) as the assessment and reporting units. The time horizon of the assessment will consist of baseline (2001 to 2010) and future potential capacities (2011 to 2050). Current and future carbon stocks and GHG emissions will be estimated on the basis of the socioeconomic and climate characteristics of three storylines (A1B, A2, and B1) from the IPCC's Special Report on Emission Scenarios (SRES; Nakicenovic and others, 2000). One reference and three enhanced scenarios (varying land cover and land management) are associated with each of the IPCC SRES storylines; in addition, the assessment will consider the concept of potential natural vegetation as a scenario (fig. 3). Carbon and GHG-flux estimates will be produced for the time horizon and scenarios using national datasets (such as forest inventories and soil databases) and empirical and process-based models. Finally, the assessment will also provide a context for examining uncertainties, studying the effects of increased sequestration on other ecosystem services, and developing carbon-monitoring capabilities.

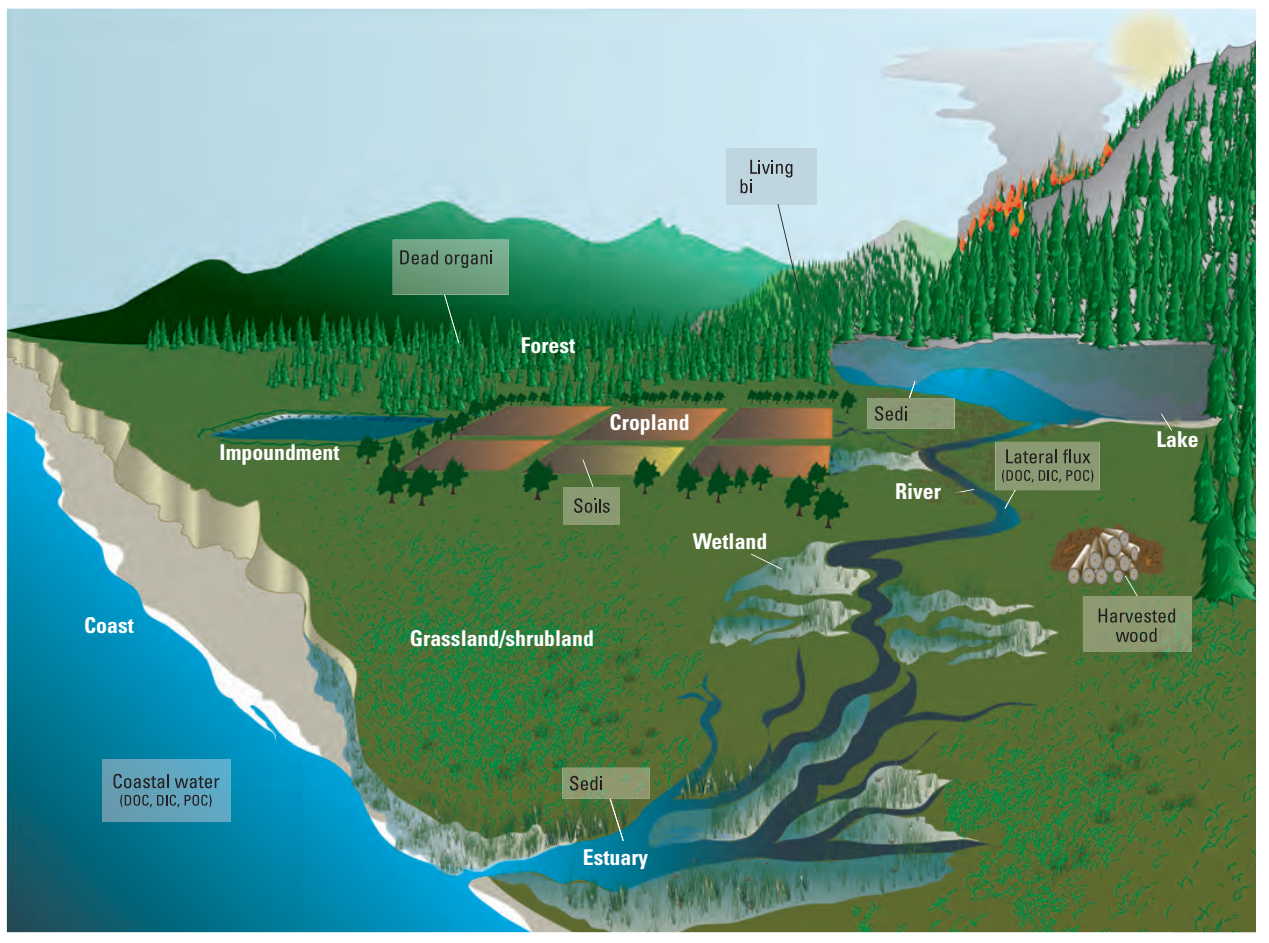

Figure 1. Diagram showing terrestrial ecosystems covered in the assessment, including forests, grasslands/shrublands, croplands, and wetlands. The carbon pools within terrestrial ecosystems include aboveground and belowground biomass, organic matter such as dead wood and litter, soils and sediments, and harvested wood. Aquatic systems include rivers, lakes, impoundments, estuaries, and coastal areas. Dissolved organic carbon (DOC), dissolved inorganic carbon (DIC), and particulate organic carbon (POC) are the main carbon pools that will be measured in coastal and surface waters. The Energy Independence and Security Act of 2007 (U.S. Congress, 2007) defined the boundaries of the assessment so that it does not extend beyond coastal waters. Representative examples of carbon pools are highlighted within the diagram. 

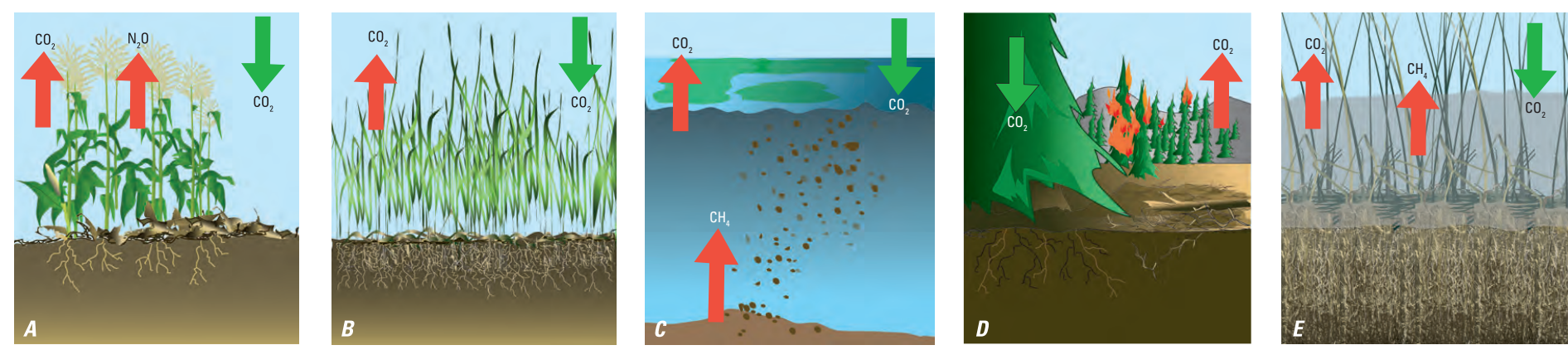

Figure 2. Diagrams showing examples of measured greenhouse-gas (GHG) fluxes in representative ecosystems. The three GHGs covered in the assessment are carbon dioxide $\left(\mathrm{CO}_{2}\right)$, nitrous oxide $\left(\mathrm{N}_{2} \mathrm{O}\right)$, and methane $\left(\mathrm{CH}_{4}\right)$. Across all ecosystems, $\mathrm{CO}_{2}$ is emitted via biomass decomposition and respiration, and $\mathrm{CO}_{2}$ is taken up by photosynthesis. $A$, Croplands. Because of fertilizer amendments to cropland soils, emission of $\mathrm{N}_{2} \mathrm{O}$ via denitrification often occurs from this ecosystem. $B$, Grasslands/shrublands. Belowground biomass and litter incorporation

\begin{tabular}{|c|c|c|c|c|}
\hline \multirow{3}{*}{\multicolumn{3}{|c|}{$\begin{array}{l}\text { IPCC } \\
\text { SRES } \\
\text { A1B }\end{array}$}} & \multicolumn{2}{|c|}{ Management } \\
\hline & & & \multicolumn{2}{|c|}{ Carbon sequestration } \\
\hline & & & Conventional & Enhanced \\
\hline \multirow{3}{*}{ 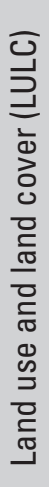 } & \multirow{3}{*}{ 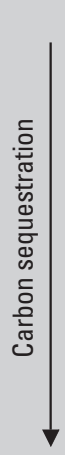 } & 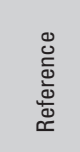 & $\begin{array}{l}\text { (R) Reference SRES } \\
\text { storyline, with LULC } \\
\text { and management } \\
\text { consistent with basic } \\
\text { SRES assumptions }\end{array}$ & $\begin{array}{l}\text { (M) Reference LULC } \\
\text { remains constant, but } \\
\text { land management is } \\
\text { optimized for carbon } \\
\text { sequestration }\end{array}$ \\
\hline & & 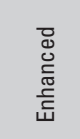 & $\begin{array}{l}\text { (L) LULC optimized for } \\
\text { carbon sequestration, } \\
\text { with conventional land } \\
\text { management }\end{array}$ & $\begin{array}{l}\text { (ML) LULC and land } \\
\text { management both } \\
\text { optimized for carbon } \\
\text { sequestration }\end{array}$ \\
\hline & & 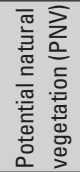 & \multicolumn{2}{|c|}{$\begin{array}{l}\text { (PNV) LULC returns to potential natural } \\
\text { vegetation form and structure. Assumption } \\
\text { of no anthropogenic alteration of landscape }\end{array}$} \\
\hline
\end{tabular}

Figure 3. Diagram showing the assessment framework for each of the three storylines (A1B, A2, and B1) of the Intergovernmental Panel on Climate Change's (IPCC) Special Report on Emissions Scenarios (SRES) (Nakicenovic and others, 2000), using storyline A1B as an example.

The primary products are intended to be regional assessment reports and derivative datasets and maps that will provide the results and analyses by defined ecosystems, pools, and scenarios. The types of information that will be presented in the reports include annual changes in carbon stocks, net ecosystem carbon balances, and estimates of GHG emissions. Users of the assessment results are likely to include public policymakers and analysts; Federal, State, and local government officials; nongovernmental organizations; individuals and community stakeholders; and the scientific community. The assessment results are intended to (1) assist in the development of mitigation opportunities and strategies, (2) promote an understanding of the adaptation needs and potential vulnerabilities under different climate-change scenarios, (3) improve the understanding of the carbon cycle and carbon sequestration in relation to natural and anthropogenic controlling processes, and (4) help support the examination of potential ancillary effects of mitigation actions on other ecosystem services. The assessment results may be used to examine questions such as- into the soil contribute to large carbon stocks in grassland soils. $C$, Aquatic ecosystems. Surface water-atmosphere exchange of $\mathrm{CO}_{2}$ occurs in water bodies. Methane results from anaerobic respiration. $D$, Forests. Large amounts of $\mathrm{CO}_{2}$ are stored in forest biomass, but carbon can be emitted through combustion of organic matter in forest fires. $E$, Wetlands. Wetlands store large amounts of carbon in organic matter, but anaerobic conditions drive $\mathrm{CH}_{4}$ emissions into the atmosphere.

- What might be the carbon sequestration capacity of a specific ecosystem under different future climate scenarios, and how do the capacity estimates vary geographically and temporally?

- How effective are management practices, such as no-till agriculture or fire suppression, on short- and long-term carbon sequestration and GHG fluxes?

- How will changes in the terrestrial supply of carbon, nutrients, and sediments to inland basins, estuaries, and coastal oceans affect carbon sequestration and GHG production in aquatic ecosystems in these areas?

The successful completion of the assessment will require collaborations among various Federal agencies, State agencies, nongovernmental organizations, and the science community in order to reduce overlaps and improve the consistency of the assessment results.

\section{References Cited}

Nakicenovic, Nebojsa, Alcamo, Joseph, Davis, Gerald, de Vries, Bert, and others, 2000, Special report on emissions scenarios; A special report of Working Group III of the Intergovernmental Panel on Climate Change [IPCC]: Cambridge, UK, Cambridge University Press, 599 p., accessed June 14, 2010, at http:/www.grida.no/publications/ other/ipcc\%5Fsr/?src=/climate/ipcc/emission/index.htm.

Omernik, J.M., 1987, Ecoregions of the conterminous United States: Annals of the Association of American Geographers, v. 77, no. 1, p. $118-125$.

U.S. Congress, 2007, Energy Independence and Security Act-Public Law 110-140: U.S. Congress, 311 p., available at http://www.gpo. gov/fdsys/pkg/PLAW-110publ140/pdf/PLAW-110publ140.pdf.

Zhu, Zhiliang, ed., Bergamaschi, Brian, Bernknopf, Richard, Clow, David, and others, 2010, A method for assessing carbon stocks, carbon sequestration, and greenhouse-gas fluxes in ecosystems of the United States under present conditions and future scenarios: U.S. Geological Survey Scientific Investigations Report 2010-5233, 190 p. (Also available at http://pubs.usgs.gov/sir/2010/5233/.) (Supersedes U.S. Geological Survey Open-File Report 2010-1144.)

\section{By Zhiliang Zhu and Sarah Stackpoole}

For more information, please contact

Zhiliang Zhu, U.S. Geological Survey

12201 Sunrise Valley Drive, MS 519

Reston, VA 20192

Email: zzhu@usgs.gov

Web page: http://rmgsc.cr.usgs.gov/carbon_seq/. 